\title{
The Isolation and Characterization of a 1,2-Propanediol Oxidoreductase from Neisseria gonorrhoeae
}

\author{
By HUGH C. MCDONALD, ${ }^{1 *}$ MILTON M. TAKEGUCHI, ${ }^{1}$ \\ CLARENCE C. DETAR, ${ }^{1}$ PAULA A. SIMON, ${ }^{1}$ KIM A. LIVSEY, ${ }^{1}$ \\ GERALD ODSTRCHEL, ${ }^{1}$ NATHAN O. KAPLAN ${ }^{2}$ AND \\ HOWARD H. WEETALL ${ }^{1}$ \\ ${ }^{1}$ Research and Development Laboratories, Sullivan Science Park, \\ Corning Glass Works, Corning, New York 14830, U.S.A. \\ ${ }^{2}$ Department of Chemistry, University of California at San Diego, \\ La Jolla, California 92093, U.S.A.
}

(Received 18 October 1979; revised 14 February 1980)

\begin{abstract}
An enzyme which oxidizes 1,2-propanediol in the presence of $\mathrm{NAD}^{+}$has been purified from lysates of Neisseria gonorrhoeae. The enzyme was activated by monovalent cations, had a pH optimum between 9 and 10, and showed a substrate specificity unlike any known alcohol or glycerol dehydrogenase. The enzyme had an apparent $K_{\mathrm{m}}$ of $17 \mathrm{~mm}$ for 1,2-propanediol and $0.37 \mathrm{~mm}$ for $\mathrm{NAD}^{+}$. When chromatographed on a Sephadex G- 150 column, the enzyme eluted as a single peak in the molecular weight region of a bovine serum albumin marker. An antibody to the purified enzyme was prepared in goats. When antiserum was reacted with the enzyme in immunodiffusion experiments, a single precipitin band was detected. When the enzyme was mixed with an excess of antibody and then reacted with substrate, enzyme activity was completely inhibited.
\end{abstract}

\section{INTRODUCTION}

Tauber \& Russell (1962) reported that Neisseria gonorrhoeae cells contained high concentrations of lactate and glutamate dehydrogenases. Recently, NADH and lactate dehydrogenases have been found in association with the cell envelope (Smyth et al., 1976) and glucose-6-phosphate dehydrogenase has been found in cytoplasmic extracts (Owen \& Smyth, 1977). This report demonstrates the isolation and initial biochemical and immunochemical characterization of a new dehydrogenase from $N$. gonorrhoeae. The enzyme is capable of oxidizing 1,2-propanediol in the presence of $\mathrm{NAD}^{+}$and is also active as a reductase in the reverse direction when reacted with $\mathrm{NADH}$ and dihydroxyacetone. The enzyme has been tentatively called propanediol oxidoreductase. It has been studied in detail for its potential value as a diagnostic marker for $N$. gonorrhoeae cells (Takeguchi et al., 1980). A previous report (McDonald et al., 1978) investigated the properties of the enzyme when bound to an immobilized antibody.

\section{METHODS}

Cultures and lysates. Neisseria gonorrhoeae strain F62 was obtained from the Center for Disease Control, Atlanta, Georgia, U.S.A. All other organisms used in this study were from well-characterized stock collections. Cells were cultivated at room temperature with shaking for 24 to $48 \mathrm{~h}$ in broth medium containing per litre) $15 \mathrm{~g}$ Proteose peptone no. 3 (Difco), $1 \mathrm{~g}$ cornstarch, $4 \mathrm{~g} \mathrm{~K} \mathrm{KPO}_{4}, 1 \mathrm{~g} \mathrm{KH}_{2} \mathrm{PO}_{4}, 5 \mathrm{~g} \mathrm{NaCl}$ and $10 \mathrm{ml}$ IsoVitalex enrichment (BBL). Cells were lysed by suspending the pellet obtained from 11 culture 
$\left(10^{7}\right.$ to $10^{8}$ cells $\left.\mathrm{ml}^{-1}\right)$ in $100 \mathrm{ml} 0 \cdot 1 \mathrm{M}$-Tris/HCl buffer, $\mathrm{pH} 9 \cdot 0$, for $1 \mathrm{~h}$ at $4^{\circ} \mathrm{C}$. Following centrifugation $(4000 \mathrm{~g}, 30 \mathrm{~min})$, the supernatant was frozen at $-17^{\circ} \mathrm{C}$. Scanning electron micrographs of cells lysed by this method showed that over $99 \%$ appeared to be disrupted. This was confirmed in plating studies of the lysate in which only a few colonies were recovered from the concentrated lysate. Lysates of Staphylococcus epidermidis were prepared as described for $N$. gonorrhoeae with lysozyme $\left(1 \mathrm{mg} \mathrm{m}^{-1}\right)$ added to aid disruption.

Enzyme isolation. Propanediol oxidoreductase was purified by affinity chromatography using AMPSepharose columns. The AMP was activated by methods developed by Lee et al. $(1974,1975)$ and the attachment of the AMP derivative to Sepharose 4B was accomplished by the method of Axen et al. (1967) using cyanogen bromide-activated Sepharose. The enzyme was isolated as follows. To a $60 \mathrm{ml}$ column of AMPSepharose, equilibrated in $0.02 \mathrm{M}$-phosphate buffer, $\mathrm{pH} 6.0$, was added $50 \mathrm{ml}$ of the gonococcal lysate diluted with an equal volume of the same buffer. Elution was with $0.03 \mathrm{M}-5^{\prime}-\mathrm{AMP}$ in the same buffer. Fractions $(3 \mathrm{ml})$ were collected and assayed for protein by absorbance at $280 \mathrm{~nm}$ and for enzyme activity. The active peak was divided and pooled as follows: (a) ascending portion, fractions 8 to 11 , (b) peak, fractions 12 to 20 , (c) descending portion, fractions 21 to 33 .

Enzyme assay. To $0.1 \mathrm{ml}$ of the enzyme preparation in a cuvette of $10 \mathrm{~mm}$ path length was added $2.9 \mathrm{ml}$ of $\mathrm{NAD}^{+} / 1$,2-propanediol reagent. (This reagent, prepared fresh daily, was $0 \cdot 1 \mathrm{M}$-Tris/HCl buffer, $\mathrm{pH} 9 \cdot 0$, containing $0.25 \mathrm{M}-\mathrm{NH}_{4} \mathrm{Cl}, 5 \mathrm{mM}-\mathrm{NAD}^{+}$and $4 \mathrm{~mm}-1,2$-propanediol.) The rate of $\mathrm{NADH}$ or $\mathrm{NAD}^{+}$formation was measured at $340 \mathrm{~nm}$ against a water blank. One unit of enzyme activity was defined as the amount of enzyme capable of producing $1 \mu \mathrm{mol} \mathrm{NAD}{ }^{+}$or $\mathrm{NADH} \mathrm{min}^{-1}$ at $23{ }^{\circ} \mathrm{C}$.

Kinetic parameters. The $\mathrm{pH}$ optimum was determined using the assay previously described omitting $\mathrm{NH}_{4} \mathrm{Cl}$ but at increasing $\mathrm{pH}$ values. All assays were at room temperature $\left(23^{\circ} \mathrm{C}\right)$, and the $\mathrm{pH}$ represents the initial reaction $\mathrm{pH}$. The optimal reaction temperature was determined by assaying samples at various time intervals at different temperatures. Temperatures were maintained at $\pm 1^{\circ} \mathrm{C}$. The effect of monovalent cations was examined by substituting other salts for the $\mathrm{NH}_{4} \mathrm{Cl}$ in the assay mixture at varying concentrations.

A series of related substrates were examined using both $\mathrm{NAD}^{+}$and NADH as the coenzyme. In addition, glycerol dehydrogenase from Aerobacter aerogenes (Sigma) and alcohol dehydrogenase from yeast (Worthington Biochemical Corp.) were examined on a comparative basis. The assays were as previously described but used $100 \mu \mathrm{l}$ of the undiluted substrates. The $K_{\mathrm{m}}$ values for NAD ${ }^{+}, \mathrm{NADH}$ and several analogues were determined graphically. In addition, several substrates other than 1,2-propanediol were examined for $K_{\mathrm{m}}$ values at $\mathrm{pH} 8 \cdot 0$ and $9 \cdot 0$.

Molecular weight estimate. Crude lysate was chromatographed on a Sephadex G-150 (Pharmacia) column $(1.5 \times 100 \mathrm{~cm})$ surrounded by a water jacket kept at $4{ }^{\circ} \mathrm{C}$ and equilibrated with $0.06 \mathrm{M}$-Tris/ $\mathrm{HCl}$ buffer, $\mathrm{pH}$ 8.5. The column flow-rate was $10 \mathrm{ml} \mathrm{h}^{-1}$ and $2 \mathrm{ml}$ fractions were collected. Fractions were assayed for protein absorbance at $280 \mathrm{~nm}$. Dehydrogenase activity was monitored by the following procedure: $0.01 \mathrm{ml}$ of each fraction was added to $0.1 \mathrm{ml}$ column buffer and the tubes were put on ice; $0.02 \mathrm{ml}$ of enzyme colour reagent (Pol-E Strat LDH-1; Pfizer, Diagnostics Division, New York, U.S.A.) containing 1,2-propanediol was added and the samples were incubated at $37^{\circ} \mathrm{C}$ for $45 \mathrm{~min}$. The reaction was quenched by the addition of $1.0 \mathrm{ml} 0.1 \mathrm{M}-\mathrm{HCl}$ and the absorbance at $540 \mathrm{~nm}$ was read against a blank containing $0.1 \mathrm{ml}$ buffer and $1.0 \mathrm{ml} 0.1 \mathrm{M}-\mathrm{HCl}$.

Immunochemical methods. The best antiserum was obtained from goat no. 284 using the following procedure. One volume of complete Freund's adjuvant was added to an equal volume of $0.01 \mathrm{M}$-phosphatebuffered saline containing 0.2 to $0.6 \mathrm{mg}$ enzyme purified by AMP-Sepharose chromatography. The animal was injected subcutaneously with $1 \mathrm{ml}$ doses for 4 consecutive weeks, rested for 4 weeks, and then boosted. This study used an antiserum pool composed of bleedings taken after the first booster injection.

The antibody content of serum was measured by the capacity of serum dilutions to inhibit the enzyme reaction. Antisera were serially diluted in the Tris/HCl buffer to give maximal enzyme activity. A total of $0.1 \mathrm{ml}$ dilute antiserum was mixed with $0.1 \mathrm{ml}$ lysate from $N$. gonorrhoeae previously calculated to give an increase of 0.01 absorbance units $\mathrm{min}^{-1}$ at $340 \mathrm{~nm}$ at $23^{\circ} \mathrm{C}$. After 30 min incubation at $23^{\circ} \mathrm{C}, 2.8 \mathrm{ml}$ substrate $\left(0.1 \mathrm{~g} \mathrm{NAD}^{+}, 1.0 \mathrm{ml}\right.$ 1,2-propanediol, $30 \mathrm{ml}$ Tris) was added. The rate of NADH formation was measured as described. The enzyme-inhibition titre of an antiserum was defined as the greatest serum dilution capable of a $50 \%$ inhibition of 24 milliunits of enzyme activity $\mathrm{ml}^{-1}$.

Ouchterlony double diffusion experiments were performed on a $1 \%(\mathrm{w} / \mathrm{v})$ agarose gel prepared in phosphate-buffered saline (PBS; 0.05 M-phosphate, $0.15 \mathrm{M}-\mathrm{NaCl}$, pH 7.3). Precipitin reactions were incubated for $48 \mathrm{~h}$ at $23^{\circ} \mathrm{C}$. Quantitative precipitin reactions were carried out with varying amounts of crude lysate and $0.1 \mathrm{ml}$ antiserum at a final volume of $1.0 \mathrm{ml}$ in PBS (Maurer, 1971). After overnight incubation at $4{ }^{\circ} \mathrm{C}$, the precipitates were washed three times with $1 \mathrm{ml}$ volumes of cold PBS. Enzyme activity was measured by adding $1.5 \mathrm{ml}$ substrate to each precipitate. After $15 \mathrm{~min}$ at room temperature, the reaction mixtures were centrifuged and the absorbance of the supernatant fluids at $340 \mathrm{~nm}$ was read. After estimating 
Table 1. Recovery of enzyme from the AMP-Sepharose column

\begin{tabular}{|c|c|c|c|c|c|}
\hline \multirow[b]{2}{*}{ Expt } & \multirow[b]{2}{*}{$\begin{array}{c}\text { Units } \\
\text { applied* }\end{array}$} & \multicolumn{3}{|c|}{ Units recovered } & \multirow{2}{*}{$\begin{array}{c}\text { Total } \\
\text { recovered } \\
(\%)\end{array}$} \\
\hline & & a & $\begin{array}{c}\text { Fraction } \\
\mathrm{b}\end{array}$ & c & \\
\hline 1 & 511 & 3 & 401 & 67 & 92 \\
\hline 2 & 719 & 2 & 524 & 54 & 81 \\
\hline 3 & 145 & 0.2 & 105 & 34 & 96 \\
\hline
\end{tabular}

\footnotetext{
* One unit represents the production of $1 \mu \mathrm{mol} \mathrm{NADH} \mathrm{min}^{-1}$ at $23^{\circ} \mathrm{C}$ in saturating concentrations of 1,2-propanediol.

$\dagger$ Fractions $\mathrm{a}, \mathrm{b}$, and $\mathrm{c}$ refer to the ascending, peak and descending portions of the eluted enzyme solution (see Methods).
}

the enzyme activity, the precipitates were washed in PBS, and their protein content was determined by the Lowry technique, using goat gamma globulin (Sigma) as a standard.

The specificity of the goat antiserum was tested in the inhibition assay using lysates prepared from laboratory cultures of Escherichia coli, Staphylococcus epidermidis and Enterobacter cloacae. These organisms were chosen for the preliminary specificity study since coliform organisms and staphylococci are often isolated from the genital tract (Corbishley, 1977). The propanediol dehydrogenase-like activity of these organisms was weak relative to that of similarly prepared lysates of $N$. gonorrhoeae and could not be accurately measured spectrophotometrically. Therefore, the inhibition tests were performed using a fluorimetric assay with a Turner Fluorometer Model III (Turner Associates, Palo Alto, Calif., U.S.A.) with a neutral density filter. Antiserum dilutions in Tris $/ \mathrm{HCl}$ buffer $(0.1 \mathrm{ml})$ were mixed with $0.1 \mathrm{ml}$ lysate containing 70 relative fluorescence units. After $30 \mathrm{~min}$ at $37^{\circ} \mathrm{C}, 3 \mathrm{ml}$ substrate was added, the reaction was incubated for $1 \mathrm{~h}$ at $50^{\circ} \mathrm{C}$ and the fluorescence was determined.

\section{RESULTS}

\section{Enzyme isolation}

Two protein peaks were eluted from the AMP-Sepharose column, but only one showed enzyme activity with 1,2-propanediol plus $\mathrm{NAD}^{+}$. Recoveries from three separate experiments are shown in Table 1 and generally exceeded $80 \%$ of the total enzyme activity applied. The purification factor achieved, as determined by the ratio of the specific activities of the peak pool to that of the crude lysate, was 184. Material in the peak pool was used for kinetic studies and antibody production.

\section{Kinetic studies}

The effect of various cations on enzyme activity was tested over the concentration range 0.005 to 0.5 M. Generally, multivalent cations $\left(\mathrm{Ca}^{2+}, \mathrm{Sn}^{3+}, \mathrm{Fe}^{2+}, \mathrm{Zn}^{2+}\right)$ inhibited the enzyme reaction whereas monovalent cations $\left(\mathrm{K}^{+}, \mathrm{Na}^{+}, \mathrm{NH}_{4}^{+}\right)$showed activation. Routinely, $0 \cdot 25 \mathrm{M}-\mathrm{NH}_{4} \mathrm{Cl}$ was added to all reaction buffers. The $\mathrm{pH}$ optimum of the propanediol dehydrogenase reaction was broader ( $\mathrm{pH} 9$ to 10 ) in the presence of $\mathrm{NH}_{4} \mathrm{Cl}$ than in its absence ( $\mathrm{pH} 10)$.

The optimal temperature of the dehydrogenase reaction was $50^{\circ} \mathrm{C}$, but most studies were performed at $23^{\circ} \mathrm{C}$ where the activity was approximately half that observed at $50{ }^{\circ} \mathrm{C}$. The activation energy determined between 27 and $37^{\circ} \mathrm{C}$ was $6.86 \mathrm{kcal}(28.7 \mathrm{~kJ})$. This is rather low and indicates thermal lability of the enzyme.

The specificity of the enzyme for substrates is given in Table 2. The enzyme was assayed using either $\mathrm{NAD}^{+}$or NADH and was found capable of functioning in either direction. For comparative purposes, two dehydrogenases were assayed on several of the same substrates. The results indicate that the enzyme isolated from $N$. gonorrhoeae is definitely not a glycerol dehydrogenase. Since it was most effective with $\mathrm{NAD}^{+}$on 1,2-propanediol, it was initially thought that this might be the prime substrate. However, the enzyme was also very active with $\mathrm{NADH}$ in carrying out reduction of oxidized substrates. 
Table 2. Reactivity of $N$. gonorrhoeae oxidoreductase and related enzymes with analogues of 1,2-propanediol and 1-hydroxypropanone

Substrate $\overbrace{\begin{array}{l}N . \text { gonorrhoeae } \\ \text { oxidoreductase }\end{array}}^{\text {Enzyme reactivity }(\%)} \begin{gathered}\begin{array}{c}\text { Aerobacter } \\ \text { glycerol } \\ \text { dehydrogenase }\end{array} \\ \begin{array}{c}\text { Yeast } \\ \text { alcohol } \\ \text { dehydrogenase }\end{array}\end{gathered}$

(a) Oxidation

1,2-Propanediol

Glycerol

1,2-Butanediol

1,3-Propanediol

1,2-Ethanediol

1-Chloro-2,3-propanediol

Dihydroxyacetone

Ethanol

1-Propanol

2-Propanol

1-Butanol

Lactic acid

100
1
10
0
0
0
21
0
0
0
0
0

100
63
13
42
53
53
74
5
0
13
0
0

1

0

2

0

2

0

25

100

121

4

9
0

(b) Reduction

1-Hydroxypropanone* 100

Dihydroxyacetone 193

2,3-Butanedione 0

3-Hydroxy-2-butanone $\quad 110$

* The reactivity with 1-hydroxypropanone, taken as $100 \%$, is only comparable with the other three compounds tested in that group $(b)$ with $\mathrm{NADH}$; it is not directly comparable with the oxidation reactions.

\section{Table 3. Kinetic studies on $N$. gonorrhoeae oxidoreductase}

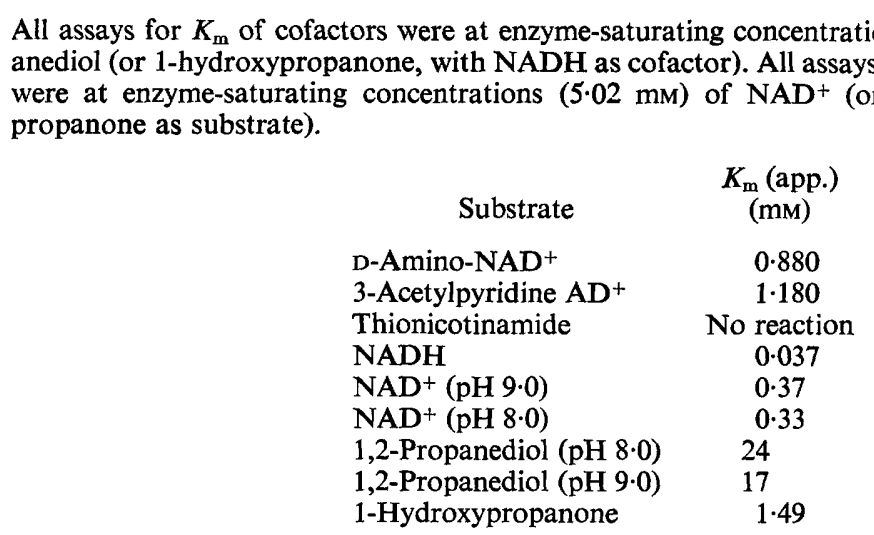

Kinetic studies were performed using a series of $\mathrm{NAD}^{+}$analogues as cofactors and 1,2-propanediol as the substrate. In addition, NADH was examined using 1-hydroxypropanone as the substrate (Table 3). The results indicated that NADH gives a lower apparent $K_{\mathrm{m}}$ value as substrate than $\mathrm{NAD}^{+}$by a factor of at least ten. Similarly, the apparent $K_{\mathrm{m}}$ values for 1,2-propanediol and 1-hydroxypropanone indicated that the $K_{\mathrm{m}}$ for 1 -hydroxypropanone is 11 times lower than that for 1,2-propanediol. Based on these results it is possible that the enzyme may normally act as a reductase rather than a dehydrogenase.

\section{Molecular weight determination on Sephadex G-150}

When crude lysate was chromatographed on a Sephadex G-150 column, the major protein peaks did not coincide with the area of greatest enzyme activity. Propanediol dehydrogenase 


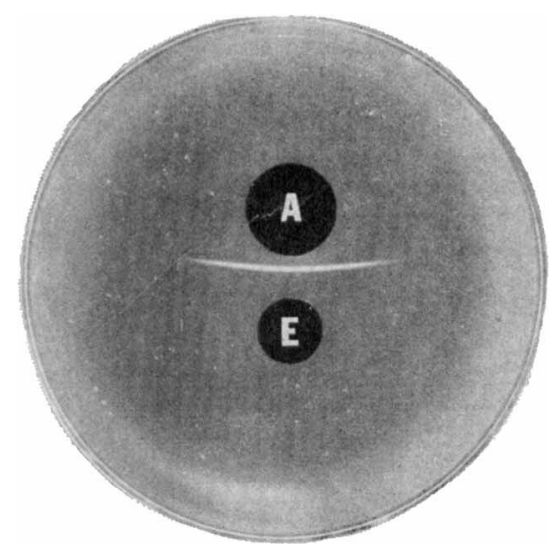

Fig. 1. Agar gel precipitin reaction between 0.6 units of purified enzyme (E) and goat antiserum (A).

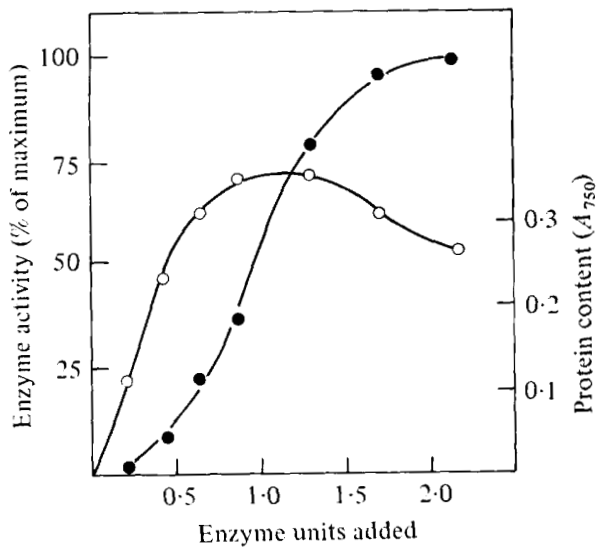

Fig. 2

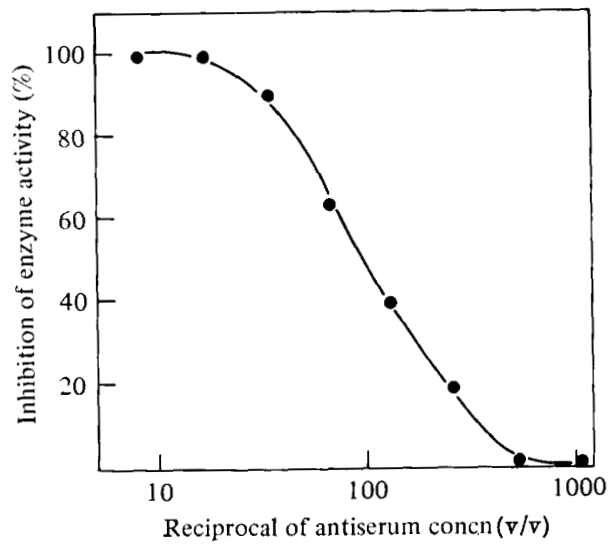

Fig. 3

Fig. 2. Quantitative precipitin reaction between $N$. gonorrhoeae lysate and goat antiserum $(0 \cdot 1 \mathrm{ml})$. Protein content $(O)$ was determined by the Lowry method and readings were taken at $750 \mathrm{~nm}$. Enzyme activity (O) was determined as described in Methods.

Fig. 3. Titration curve of antiserum inhibition of enzyme activity. Neisseria gonorrhoede lysate $(0 \cdot 1 \mathrm{ml})$ containing 75 milliunits of enzyme activity was incubated with $0.1 \mathrm{ml}$ of each serum dilution for $30 \mathrm{~min}$ at $23^{\circ} \mathrm{C}$. Substrate $(2.8 \mathrm{ml})$ was then added and the NADH formed was determined by rate measurement on a spectrophotometer at $340 \mathrm{~nm}$.

activity was detected in one symmetrical peak in the region where a bovine serum albumin (molecular weight 68000) marker protein would elute. Additional molecular weight studies were performed on the purified enzyme using polyacrylamide gel electrophoresis in $0.1 \%$ $(\mathrm{w} / \mathrm{v})$ sodium dodecyl sulphate solution. Compared to reference proteins (bovine serum albumin, ovalbumin, RNAase) run in parallel acrylamide $(7.5 \%, \mathrm{w} / \mathrm{v})$ gels, the major protein band of the enzyme was caiculated to have a molecular weight of 36000 . These studies suggested that the enzyme may be composed of two subunits.

\section{Immunochemical characterization}

Ouchterlony immunodiffusion experiments with goat antiserum and partially purified enzyme showed one distinct precipitin band (Fig. 1) which contained active enzyme when reacted with the colorimetric enzyme substrate (not shown). Figure 2 shows the results of a quantitative precipitin reaction between goat antiserum and crude gonococcal lysate. A 


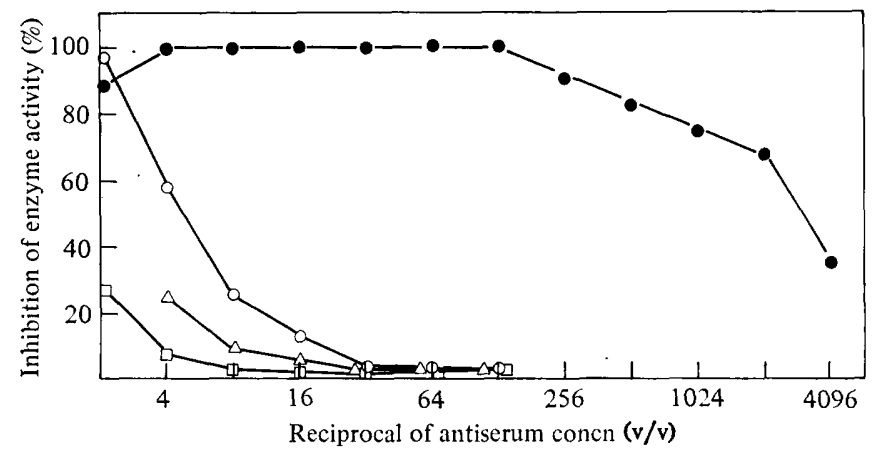

Fig. 4. Inhibition potency of goat antisera against lysates from $S$. epidermidis $(\square)$, E. coli $(\triangle)$, Ent. cloacae $(O)$ and $N$. gonorrhoeae $(O)$. The assay was performed in the fluorimeter and all lysates were adjusted to 70 relative fluorimeter units before the addition of antiserum.

precipitin curve was generated with an estimated equivalence point of 1 unit of enzyme activity per $0.1 \mathrm{ml}$ antiserum. The protein concentration of the equivalence precipitates indicated that the antiserum contained $65 \mu \mathrm{g}$ precipitable antibody $\mathrm{ml}^{-1}$.

Although immunoprecipitates between enzyme and antibody were enzymically active, excess antibody completely inhibited the dehydrogenase reaction. Figure 3 shows an inhibition curve obtained from rate measurements on a spectrophotometer. When a similar experiment was performed using a fluorimeter - a more sensitive method - complete inhibition was also observed. No sera were found in which the enzyme activity was enhanced due to the presence of antibody, and normal goat serum showed no inhibition.

The specificity of the inhibition reaction was investigated with bacterial lysates having propanediol dehydrogenase-like activity (Fig. 4). Lysates from $E$. coli, S. epidermidis and Ent. cloacae were inhibited at serum dilutions less than 1:10. However, they were not inhibited at the higher antibody dilutions capable of inhibiting propanediol dehydrogenase from $N$. gonorrhoeae. At the $50 \%$ inhibition level, the titre for the $N$. gonorrhoeae enzyme was $1: 3000$ compared with less than 1:8 for the other organisms. Additional specificity studies were performed using lysates from Gram-negative coccoid bacteria. These studies showed that 1,2-propanediol dehydrogenase was present in most members of the genus Neisseria and was inhibited by antibody prepared against the $N$. gonorrhoeae enzyme. The only non-Neisseria organisms with a 1,2-propanediol dehydrogenase that was significantly inhibited by antibody were members of the genus Acinetobacter.

\section{DISCUSSION}

To our knowledge this is the first report of a propanediol oxidoreductase in $N$. gonorrhoeae. Similar enzymes have been reported in a soil pseudomonad (Lowe \& Turner, 1968), in E. coli wild-type (Lowe \& Turner, 1968, 1970), in E. coli mutants (Sridhara et al., 1969), in anaerobically cultured E. coli (Cocks et al., 1974; Boronat \& Aguilar, 1979), and in a soil bacterium isolated by Tanaka et al. (1975). Based on substrate specificity, the gonococcal enzyme and the soil bacterium dehydrogenase (Tanaka et al., 1975) were the most similar. Both enzymes showed little or no activity with glycerol and ethanol in the dehydrogenase reaction, and both enzymes utilized 1-hydroxypropanone and dihydroxyacetone in the reductase reaction. The $K_{\mathrm{m}}$ for 1,2-propanediol was $30.9 \mathrm{~mm}$ for the soil bacterium, rather similar to the gonococcal oxidoreductase value of $17 \mathrm{~mm}$. In contrast, the enzyme from the $E$. coli mutant and the enzymes from anaerobically cultured $E$. coli all showed good reactivity with ethanol and glycerol. In addition, the enzyme from the $E$. coli mutant required divalent cations for activity. The gonococcal enzyme's metal ion requirement was quite 
different as polyvalent cations inhibited the reaction and monovalent cations, especially $\mathrm{NH}_{4}{ }^{+}$, enhanced the reaction. In this respect, the gonococcal enzyme is similar to the soil pseudomonad enzyme and the $E$. coli wild-type enzyme (Lowe \& Turner, 1968) which were activated by $\mathrm{NH}_{4}{ }^{+}$and were highly reactive with diols and hydroxyacetones.

At present, we do not know what the oxidation product of the propanediol dehydrogenase reaction is, nor do we know into which metabolic pathway the oxidoreductase belongs. Our kinetic studies lead us to conclude that the enzyme may normally operate as a reductase, since the $K_{\mathrm{m}}$ values for 1-hydroxypropanone and NADH were lower than the $K_{\mathrm{m}}$ values for 1,2-propanediol and $\mathrm{NAD}^{+}$.

The preparation of an antibody that would inhibit the propanediol dehydrogenase reaction was important for several reasons. First, the antibody could be used to investigate the enzyme reaction mechanism. The capacity of the antibody to completely inhibit the gonococcal propanediol dehydrogenase reaction was surprising considering the size of the substrate and may be due primarily to a reaction that is not operating in its optimal direction. Second, the antibody can be used in comparative studies between oxidoreductases in immunoprecipitin experiments or inhibition procedures. Thus, the similarity of oxidoreductases in members of the genus Neisseria was clearly demonstrated (Takeguchi et al., 1980). Third, the antibody was useful as part of a specific test for the gonococcal enzyme. Since enzymes like glycerol dehydrogenase also act on propanediol, a marker enzyme test based solely on substrate specificity would be likely to detect some cross-reactive enzymes. However, any enzyme which demonstrated propanediol dehydrogenase activity but was not inhibited by antiserum, was most probably not the gonococcal oxidoreductase. Thus, combination of a marker enzyme and its specific antibody results in a test with two checks on specificity, one at the functional level (substrate) and one at the structural level (antigenic determinants). The employment of this assay for studies on the occurrence of propanediol dehydrogenase in micro-organisms has been reported (Takeguchi et al., 1980).

We appreciate the expert assistance of S. Harrau in the preparation of this manuscript.

\section{REFERENCES}

Axen, R., Porath, J. \& ERnback, S. (1967). Chemical coupling of peptides and proteins to polysaccharide by means of cyanogen halides. Nature, London 214, 1302-1304.

Boronat, A. \& Aguilar, J. (1979). Rhamnoseinduced propanediol oxidoreductase in Escherichia coli: purification, properties, and comparison with the fucose-induced enzyme. Journal of Bacteriology 140, 320-326.

Cocks, G. T., Aguilar, J. \& Lin, E. C. C. (1974). Evolution of 1,2-propanediol catabolism in Escherichia coli by recruitment of enzymes for L-fucose and L-lactate metabolism. Journal of Bacteriology 118, 83-88.

Corbishley, C. M. (1977). Microbial flora of the vagina and cervix. Journal of Clinical Pathology 30, 745-748.

LeE, C. Y. \& KaPlan, N. O. (1975). Characteristics of 8-substituted adenine nucleotide derivatives utilized in affinity chromatography. Archives of Biochemistry and Biophysics 168, 665-676.

Lee, C. Y., Lappi, D. A., Wermuth, B., EVERse, J. \& KaplaN, N. O. (1974). 8-(6-Aminohexyl)aminoadenine nucleotide derivatives for affinity chromatography. Archives of Biochemistry and Biophysics 163, 561-569.
Lowe, D. A. \& Turner, J. M. (1968). Enzymic oxidation of D-1-amino-2-propanol by diol dehydrogenases of microbial origin. Biochimica et biophysica acta 170, 455-456.

Lowe, D. A. \& TuRNer, J. M. (1970). Microbial metabolism of amino ketones: D-1-aminopropan2-ol and aminoacetone metabolism in Escherichia coli. Journal of General Microbiology 63, 49-61.

MaUreR, P. H. (1971). The quantitative precipitin reaction. Methods in Immunology and Immunochemistry 3, 1-58.

McDonald, H. C., Weetall, H. H., Simon, P., TAKeguCHI, M. \& OdSTRChEL, G. (1978). Characterization of an immobilized antibody-enzyme complex. Journal of Solid-Phase Biochemistry 3, 151-160.

OWEN, P. \& SMYTH, C. J. (1977). Enzyme analysis by quantitative immunoelectrophoresis. In Immunochemistry of Enzymes and Their Antibodies, pp. 147-202. Edited by M. R. J. Salton. New York: John Wiley.

Smyth, C. J., Friedman-Klein, A. E. \& Salton, M. R. J. (1976). Antigenic analysis of Neisseria gonorrhoeae by crossed immunoelectrophoresis. Infection and Immunity 13, 1273-1288. 
Sridhara, S., Wu, T. T., Chused, T. M. \& Lin, E. C. C. (1969). Ferrous-activated nicotinamide adenine dinucleotide-linked dehydrogenase from a mutant of Escherichia coli capable of growth on 1,2-propanediol. Journal of Bacteriology 98, 87-95.

Takeguchi, M. M., Livsey, K. A., Detar, C. C., McDonald, H. C., Smith, D. K., Simon, P. A. \& WeEtall, H. H. (1980). The occurrence of 1,2propanediol oxidoreductase in micro-organisms and its use as a possible diagnostic marker for Neisseria gonorrhoeae. Journal of General Microbiology 119, 459-464.
Tanaka, J., FujiI, K., Tanaka, A. \& FukuI, S. (1975). Properties of 1,2-propanediol-dehydrogenating enzyme from a 1,2-propanediol-utilizing soil bacterium. Journal of Fermentation Technology 53, 566-568.

Tauber, H. \& Russell, L. (1962). Enzymes of Neisseria gonorrhoeae and other Neisseria. Proceedings of the Society for Experimental Biology and Medicine 110, 440-443. 